\title{
An overview of recent research in marine biological invasions
}

\author{
Farrah T. Chan ${ }^{1} \cdot$ Elizabeta Briski $^{2}$
}

Received: 8 April 2017 / Accepted: 25 April 2017 / Published online: 3 May 2017

(c) The Author(s) 2017. This article is an open access publication

\begin{abstract}
The Topical Collection on Invasive Species includes 50 articles addressing many tenets of marine invasion ecology. The collection covers important topics relating to propagule pressure associated with transport vectors, species characteristics, attributes of recipient ecosystems, invasion genetics, biotic interactions, testing of invasion hypotheses, invasion dynamics and spread, and impacts of nonindigenous species. This article summarizes some of the collection's highlights.
\end{abstract}

Keywords Alien species - Aquatic ecosystems ·

Biodiversity · Exotic species · Nonindigenous species ·

Non-native species $\cdot$ Invasive species

\section{Introduction}

The introduction and establishment of nonindigenous species (NIS) beyond their natural distributional range is a key component of global environmental change (Simberloff et al. 2013). While only a small proportion of introduced NIS become invasive in the recipient habitats (Blackburn et al. 2011), their impacts can be detrimental. Invasive

Responsible Editor: U. Sommer.

This article is part of the Topical Collection on Invasive Species.

Farrah T. Chan

Farrah.Chan@dfo-mpo.gc.ca

1 Great Lakes Laboratory for Fisheries and Aquatic Sciences, Fisheries and Oceans Canada, Burlington, ON L7S 1A1, Canada

2 GEOMAR, Helmholtz Centre for Ocean Research Kiel, Düsternbrooker Weg 20, 24105 Kiel, Germany
NIS can lead to declines or even extinctions of native species, disrupt ecosystem functions, enhance transmission of viruses and pathogens, and cause substantial damage to natural resources and ecosystem services (Simberloff et al. 2013). Consequently, considerable research has been conducted to examine the biology, ecology, and evolution of NIS (e.g., Sakai et al. 2001; Roman and Darling 2007; Lejeusne et al. 2014), characterize key transport vectors and pathways (i.e., transport means and geographic routes, respectively) (e.g., Hulme 2009; Wilson et al. 2009), identify determinants of invasion success (e.g., Kolar and Lodge 2001; Williamson 2006; Blackburn et al. 2015), forecast spatial distribution and spread (e.g., Muirhead and MacIsaac 2005; Floerl et al. 2009; Larson et al. 2014), as well as assess and predict impacts of NIS on recipient communities (e.g., Dick et al. 2013; Alexander et al. 2014; Jeschke et al. 2014). Understanding the mechanisms and patterns of biological invasions allows us to develop strategies to prevent and manage the negative effects of NIS (Pyšek and Richardson 2010), while gaining valuable insights into ecological, evolutionary, and biogeographic theories and concepts (see Lodge 1993; Sax et al. 2007; Jeschke 2014).

Research efforts in invasion ecology; however, vary across systems, with the majority of studies conducted in terrestrial habitats rather than aquatic ones (Jeschke et al. 2012; Lowry et al. 2012). Marine and coastal ecosystems worldwide are being invaded at extraordinary rates as a result of human activities such as shipping, aquaculture, fisheries, ornamental and live seafood trades, the opening and construction of canals, habitat modification, and climate change, which provide increasing opportunities for marine NIS to be introduced and subsequently established in new environments (Occhipinti-Ambrogi and Savini 2003; Molnar et al. 2008; Williams et al. 2013). Therefore, studies focusing on biological invasions in marine and coastal environments are warranted. 
This Topical Collection on Invasive Species compiles 50 articles, including 44 Original Papers, four Reviews, and two Short Notes, addressing a wide array of topics in marine invasion ecology. Additionally, the collection is complemented by two Editorial Comments, a preface (Briski and Chan 2015) and this summary. The topics of these articles can be broadly categorized into eight themes: propagule pressure associated with transport vectors, species characteristics, attributes of recipient ecosystems, invasion genetics, biotic interactions, invasion hypothesis testing, invasion dynamics and spread, and impacts of nonindigenous species. This collection covers a number of nonindigenous algae, macrophytes, invertebrates, and fishes in marine and coastal ecosystems spanning from as far south as Argentina and New Zealand to as far north as the Canadian Arctic. The range of approaches used in the studies includes field surveys, field experiments, laboratory experiments, bioassays, literature reviews, meta-analyses, and mathematical modelling. Here, we briefly summarize some of the highlights of this collection, while a detailed description of each study can be found in the original paper. Although many studies addressed more than one topic, we focus on the most interesting and important findings of each publication for the sake of brevity.

\section{Propagule pressure associated with transport vectors}

A number of theoretical and empirical studies have demonstrated that propagule pressure- the number of individuals involved in an introduction event (propagule size) and the number of introduction events (propagule number)-is the most consistent predictor of invasion success (e.g., Von Holle and Simberloff 2005; Lockwood et al. 2005; Simberloff 2009). Increased propagule size and propagule number enhance the probability of establishment of a population by decreasing environmental and demographic stochasticity, respectively (Lockwood et al. 2005; Simberloff 2009; Blackburn et al. 2015). Transport vectors influence the movement, quantity, and quality of propagules being delivered to new habitats, thereby playing a crucial role in determining the outcome of biological invasions (Lockwood et al. 2005; Hulme 2009; Wilson et al. 2009).

This collection covers two leading transport vectors of NIS in marine and coastal ecosystems: shipping (ballast water and biofouling) and aquaculture. Casas-Monroy et al. (2016) presented the first estimation of propagule pressure for viable (i.e., alive and able to reproduce) nonindigenous dinoflagellates in ballast water of commercial ships arriving at Pacific and Atlantic ports in Canada. The authors found that propagule pressure varied by transport pathway, and that ballast water exchange was not sufficient to reduce ballast-mediated invasion risk in marine and coastal habitats. Three studies evaluating the importance of ship biofouling as a vector for the introduction and spread of marine NIS reported mixed results (Chan et al. 2016; Kauano et al. 2017; van der Gaag et al. 2016). The first study examining temporal changes in biofouling assemblages on military vessels during transits in the marine Arctic recorded six potential NIS capable of surviving round trip voyages from temperate to arctic ports in Canada (Chan et al. 2016). Similarly, an experimental study found that the sailing speed and desiccation time typical of small fishing and recreation boats in southern Brazil had little effect on the survivorship of biofouling organisms (Kauano et al. 2017). In contrast, results from mesocosm experiments indicate that the nonindigenous mussels Dreissena polymorpha and Mytilopsis leucophaeata and the native mussel Mytilus edulis would not be capable of tolerating unfavourable salinity levels for durations typical of actual ship voyages in the North Sea (van der Gaag et al. 2016). In terms of the aquaculture vector, a laboratory study demonstrated that transplanted mussels could serve as a transport vector for Nitzschia bizertensis, a new toxin-producing diatom recently found in Bizerte Lagoon, Tunisia; the diatom was able to survive, regrow, and retain its toxicity following filtration and ejection as biodeposits by mussels (Bouchouicha-Smida et al. 2015).

\section{Species characteristics}

Species characteristics such as fast growth, polyphagy, high dispersal ability, broad physiological tolerance, high genetic variability, high phenotypic plasticity, and association with humans have been proposed as common attributes of successful NIS (e.g., Sakai et al. 2001; Kolar and Lodge 2002; Jeschke and Strayer 2006; Blackburn and Jeschke 2009; Lenz et al. 2011). Articles in this collection focused on the importance of physiological tolerance to the invasion success of marine NIS. Species with the capacity to tolerate broader abiotic conditions may have a greater likelihood of surviving transport, establishing in new habitats, and expanding their introduced range (Lenz et al. 2011; Bates et al. 2013). An experimental study investigating the effects of temperature and salinity on the performance of the nonindigenous kelp Undaria pinnatifida and two native kelps, Lessonia variegata and Ecklonia radiata, from Tauranga Harbour, New Zealand found that the NIS generally exhibited broader tolerance to the treatments than the native ones (Bollen et al. 2016). Indeed, a separate study reported that the nonindigenous population of $U$. pinnatifida in Hauraki Gulf, New Zealand was able to tolerate temperatures much warmer than those in its native range by adjusting its growth cycle, allowing individuals to persist 
under conditions previously thought to be unfavourable (James and Shears 2016a).

Differential physiological tolerance between native and nonindigenous populations of a species suggests that the trait may be selected during the invasion process (Hammann et al. 2016; Schmidt et al. 2016). Comparisons of the physiological responses of native and nonindigenous populations of the seaweed Gracilaria vermiculophylla to heat shock in common-garden experiments conducted in both the native (Qingdao, China) and introduced (Kiel, Germany) ranges suggest that the nonindigenous populations are more tolerant to heat stress than the native ones (Hammann et al. 2016). Similarly, two populations of the foraminifera Amphistegina lobifera-one from the Gulf of Aqaba that invaded the Red Sea during the post-glacial recolonization, and a recently-invaded Lessepsian population from the Eastern Mediterranean-exhibited exceptional thermal resistance that has no apparent adaptive relevance to the local environments (Schmidt et al. 2016).

Within a population, differences in physiological tolerance between sex and growth phases may have implications for invasion success. Pennoyer et al. (2016) reported that individuals in the green colour phase of the nonindigenous European green crab Carcinus maenas from Maine, USA typically performed better than those in the red colour phase under conditions of low salinity, and that females often outperformed males in their respective colour phases.

\section{Attributes of recipient ecosystems}

Once arrived at new habitats, successful NIS must survive ambient environmental conditions and establish a selfsustaining population (Blackburn et al. 2011). Ecosystems that are susceptible to invasions tend to have environmental conditions similar to those of the native habitat of invading NIS, high environmental heterogeneity, a history of habitat disturbance, low species diversity, and few natural enemies (e.g., Levine et al. 2004; Fridley et al. 2007; Melbourne et al. 2007; Herborg et al. 2007; Clark and Johnston 2011). In fact, a review study identified a network of anthropogenic (e.g., physical disturbance, increased sedimentation, eutrophication, and fishing), abiotic (e.g., substrate complexity and water movement), and biotic (e.g., the presence of canopy macrophytes, alga turfs, other NIS, and herbivory) variables that regulate the spread of the nonindigenous green macroalgae Caulerpa cylindracea in the Mediterranean Sea (Piazzi et al. 2016).

Human-modified habitats such as shipping ports, marinas, and aquaculture sites may serve as hotspots for marine invasion owing to high propagule supply and/ or abiotic features that promote NIS establishment. An examination of invasion patterns in shipping ports on the Atlantic and Pacific coasts of Canada revealed that latitude, salinity, sediment type, and human populations were strongly related to NIS establishment (Choi et al. 2016). While summer water temperature and cargo shipping traffic explained the majority of variability in the number of fouling NIS established in coastal regions of the United States (Lord et al. 2015), a study investigating the association between the presence of NIS and physical features of marinas in the United Kingdom identified freshwater input, marina entrance width, and seawall length as significant predictors of NIS occurrence (Foster et al. 2016). Populations of the nonindigenous kelp $U$. pinnatifida on mussel farms were more prolific, with longer annual presences and greater reproductive capacity than those on natural reefs, because aquaculture sites provided the optimal environmental conditions (e.g., high water clarity and great water motion) for NIS establishment (James and Shears 2016b).

While classical invasion theory suggests that disturbance promotes invasion by freeing resources and reducing competition (Elton 1958; Davis et al. 2000), its influence on invasion success appears to be complex, depending on species and ecosystem properties, type and timing of disturbance, and spatial scale (e.g., Lonsdale 1999; Melbourne et al. 2007; Clark and Johnston 2011). An experimental study reported that colonization by the nonindigenous isopod Cirolana harfordi from Sydney Harbour, Australia was facilitated by the presence of an assemblage and influenced by the type of resident assemblage, with greater success on disturbed assemblages than undisturbed ones (Bugnot et al. 2016). The type of disturbance was important, as an alternative source of organic matter simulating the effects of disturbance occurring upstream of the study site had no influence on colonization (Bugnot et al. 2016). In contrast, results of two empirical studies conducted in New Zealand suggest that disturbance had limited effects on the recruitment of $U$. pinnatifida (Morelissen et al. 2016; South and Thomsen 2016). The timing and size of native algal cover removal did not affect the recruitment of $U$. pinnatifida on experimental plots located on a rock low-intertidal shore in central New Zealand (Morelissen et al. 2016). Similarly, while native canopy removal facilitated the recruitment of U. pinnatifida on experimental plots in Lyttelton Harbour, New Zealand, the nonindigenous kelp had weak and transient impacts on the native assemblages during the early stage of the invasion at a small spatial scale (South and Thomsen 2016). The study concluded that the kelp was a "passenger", not "driver", of ecological change (South and Thomsen 2016). 


\section{Invasion genetics}

Evolutionary processes (e.g., genetic bottleneck, genetic drift, selection, admixture, and adaptation) can strongly influence whether invading NIS can persist and proliferate in introduced environments (Sakai et al. 2001; Lee 2002; Roman and Darling 2007). Johnson et al. (2016) presented the first study that examined the genetic composition of the lionfish Pterois volitans/miles in the Gulf of Mexico, which suggests that the nonindigenous populations likely originated from the Caribbean and expanded rapidly after initial colonization, despite undergoing a genetic bottleneck. The first genetic study conducted for nonindigenous populations of the sponge Paraleucilla magna in the Mediterranean and Northeastern Atlantic revealed that the invasion success of the species could be attributed to high genetic diversity, likely owing to multiple introductions and phenotypic plasticity (Guardiola et al. 2016). A study examining the temporal genetic structure and diversity of a nonindigenous population of the ascidian Styela plicata in Wilmington, North Carolina, USA found that the population was maintained by a recurrent arrival of propagules from neighbouring populations, supplementing the genetic pool with new alleles after exposure to periodic floods and fluctuations in temperature and salinity (Pineda et al. 2016). Using cytochrome c oxidase subunit I barcoding sequences, Sun et al. (2017) examined the genetic divergence among global populations of the calcareous tube worm Hydroides dianthus. The authors demonstrated that $H$. dianthus is a species complex consisting of two phylogenetic lineages (Clades A and B). Interestingly, results of the study suggest that the native range of $H$. dianthus might be the Mediterranean, rather than the east coast of USA as previously assumed (Sun et al. 2017).

Recent advances in genomics tools can further improve our understanding of the role of evolutionary processes in determining the success of marine NIS. In a review paper, Sherman et al. (2016) discussed how genomic (DNA), transcriptomic (RNA), and epigenetic tools can be used to identify adaptive variation within and among (native and nonindigenous) populations, to uncover candidate genes responsible for certain adaptive traits, and to understand the mechanism of epigenetic variation in plastic responses to novel environments. In particular, high-throughput sequencing (HTS)-based methods have been used as tools for early detection and monitoring of marine NIS owing to their high capacity to detect species at low abundance with low associated costs (Zhan et al. 2013; Carugati et al. 2015; Simmons et al. 2016). Xiong et al. (2016) outlined the major technical issues that can lead to false negatives and false positives when employing these methods, discussed the causes and consequences of these errors, and offered solutions for future studies.

\section{Biotic interactions}

Biotic interactions may promote or impede the establishment and spread of NIS in recipient environments via mechanisms such as competition, exploitation, facilitation, and mutualism (e.g., Simberloff and Von Holle 1999; Freestone et al. 2013; Alofs and Jackson 2014). This collection explores the effects of facilitation, kleptoparasitism, scavenging, herbivory, predation, and competition on invasion success of marine NIS. An example in which biotic interactions facilitated the establishment of a marine NIS is provided by Drouin et al. (2016). The abundance of the nonindigenous green alga Codium fragile ssp. fragile in an eelgrass habitat in Grande-Entrée Lagoon (Magdalen Islands, Eastern Canada) was positively related to the density of the native canopy-forming species Zostera marina (Drouin et al. 2016). The native species may be essential to the establishment of $C$. fragile by trapping sediments and algal fragments, providing substrata for anchorage (Drouin et al. 2016). In contrast, Silva et al. (2017) found that native sponges (e.g., Iotrochota arenosa and Scopalina ruetzleri) may occasionally outcompete nonindigenous Tubastraea corals in Ilha Grande Bay, Brazil by overgrowing them, though the most common competitive interaction among the species is contact without dominance.

The influence of biotic interactions on the invasion success of marine NIS; however, may be less straightforward. For instance, mathematical models examining the trophic interactions among the nonindigenous green $\mathrm{crab}$ C. maenas and the native dogwhelk Nucella lapillus foraging on Mytilus spp. mussels in Atlantic Canada revealed that crab kleptoparasitism (i.e., crabs taking mussels from whelks) had negative effects on whelks, whereas no significant impact on whelks was detected for crab scavenging (i.e., crabs feeding on mussels abandoned by whelks) (Quinn and Boudreau 2016). A study examining the impact of a native herbivorous reef fish, the bluespine unicornfish (Naso unicornis), on the growth and distribution of the nonindigenous Gracilaria salicornia in the Hawaii Marine Laboratory Refuge reported that the unicornfish might serve as both a control agent and a natural transport vector for G. salicornia (Bierwagen et al. 2017). Finally, results of laboratory experiments suggest that a complex habitat mediated the negative effects of predation on the native mud crab Dyspanopeus sayi by the nonindigenous European green crab C. maenas in Atlantic Canada (Gehrels et al. 2016). 


\section{Invasion hypothesis testing}

Several hypotheses have been proposed to explain successful invasions (Catford et al. 2009; Jeschke et al. 2012; Lau and Schultheis 2015). However, these hypotheses have been tested mostly in terrestrial systems rather than aquatic ones, and the results are inconsistent (Ricciardi and MacIsaac 2011; Jeschke et al. 2012). Studies in this collection empirically tested the enemy-release hypothesis (ERH), the novel weapon hypothesis (NWH), and the evolution of increased competitive ability (EICA) hypothesis in marine and coastal habitats. The ERH proposes that NIS are liberated from the negative effects of co-evolved natural enemies, and are thus able to establish and/or cause detrimental impacts in introduced environments (Elton 1958; Colautti et al. 2004; Prior et al. 2015). In the same vein, the NWH suggests that the success of NIS is related to their competitive, defensive, or predatory traits, which native species have never encountered before in invaded habitats (Callaway and Ridenour 2004). The EICA hypothesis states that the escape from natural enemies allows NIS to reallocate resources from defense to growth and competitive ability via evolutionary mechanisms (Blossey and Nötzold 1995). Three studies examining the feeding preference of native invertebrate grazers for nonindigenous algae (Sargassum muticum, Heterosiphonia japonica, and $U$. pinnatifida) and a number of native competitors in pair-wise and multiple-choice feeding assays found that the grazers generally preferred native algae over the nonindigenous ones because they were deterred by the chemical properties (e.g., secondary metabolites) of the invaders (Jiménez et al. 2015; Sagerman et al. 2015; Schwartz et al. 2016). These results are consistent with the ERH and EICA hypotheses. In addition, the grazers' preference for $S$. muticum from the invaded habitat (North Sea) over the ones from the native range (Japan) could indicate a resource allocation from chemical defense to reproduction and growth, which is in line with the EICA hypothesis (Schwartz et al. 2016).

Results of two studies; however, did not support the ERH (Merella et al. 2016; Pedersen et al. 2016). Pedersen et al. (2016) demonstrated that the nonindigenous brown alga $S$. muticum was typically consumed at the same rate or faster than a range of native algae, depending on the growth rate and morphology of algal species being compared in feeding experiments. A parasitological study of the nonindigenous bluespotted cornetfish (Fistularia commersonii) in the Mediterranean Sea found no evident decrease of parasite richness and levels of infection in the fish (Merella et al. 2016). In fact, the species acquired new parasites while retaining a subset of natural ones in the invaded range (Merella et al. 2016).

\section{Invasion dynamics and spread of NIS}

Analyzing invasion patterns of NIS can provide insights into the drivers and mechanisms of biological invasions (e.g., Marini et al. 2013; Ruiz et al. 2013; Gallardo and Aldridge 2015) and permit the projections of future spread (e.g., Peterson 2003; Chu et al. 2005; Herborg et al. 2007). Knowledge of current and future distributions of NIS allows resource managers to prioritise control and prevention efforts at high-risk sites. For example, an examination of temporal and spatial patterns of ascidian invasions in the continental United States and Alaska identified an invasion hotspot on the Pacific coast and ship biofouling as the primary transport vector (Simkanin et al. 2016). In addition, a review of ascidian invasions worldwide provided by Zhan et al. (2015) outlined the invasion history and impacts of nonindigenous ascidians, factors underlying the success of these invasions, and relevant regulations and management strategies that are available to prevent and control further spread. Similarly, Marchini and Cardeccia (2017) presented a comprehensive inventory of global marine nonindigenous amphipods and their distributions worldwide, allowing for horizon-scanning initiatives, predictive species distribution modelling, as well as NIS monitoring. The authors also highlighted a number of knowledge gaps, notably the challenges in assessing the invasion status of species with certainty owing to taxonomic problems and dubious species records (Marchini and Cardeccia 2017).

A study modelling the connectivity among metapopulations of lionfish (P. volitans/miles) in the Gulf of Mexico identified the Campeche Bank as an important source of lionfish recruits to the north-eastern Gulf of Mexico (Johnston and Bernard 2017). Both Miller (2016) and Johnston and Akins (2016) developed sophisticated models to forecast the spread of newly reported NIS, the ascidian Didemnum vexillum in Southeastern Alaska and the damselfish Neopomacentrus cyanomos in the Gulf of Mexico, respectively, based on physiological tolerances and/or life history traits of species. A study comparing per capita algal resource use at different temperatures among three mussel species, the recent invader Semimytilus algosus, the established invader Mediterranean mussel Mytilus galloprovincialis, and the native Aulacomya atra, predicted that $S$. algosus will become established along the south coast of South Africa, though M. galloprovincialis will maintain dominance along the coast (Alexander et al. 2015). Podbielski et al. (2016) proposed that the sea anemone Diadumene lineata, recently discovered in Kiel Fjord in the Western Baltic Sea, could invade the Kattegat and Skagerrak regions, but not the Baltic Proper based on the critical salinity obtained from physiological assays. Finally, a study examining the physiology, life cycle constraints, and 
habitat availability of the European cuttlefish Sepia officinalis suggested that the species has the potential to expand its range to North America via the North Atlantic under climate change (Xavier et al. 2016).

\section{Impacts of nonindigenous species}

The dramatic effects of invasive species on recipient ecosystems are well recognized (Simberloff et al. 2013). This collection compiles information on the impact of over 40 marine NIS, including five well-known invaders, the killer alga Caulerpa taxifolia (Cvitkovic et al. 2017), the alga U. pinnatifida (South and Thomsen 2016), the European green crab C. maenas (Gehrels et al. 2016; Lutz-Collins et al. 2016; Quinn and Boudreau 2016), the Mediterranean mussel Mytilus galloprovincialis (Alexander et al. 2015), and the Asian date mussel Arcuatula senhousia (Como et al. 2016). The first four listed species are considered the world's worst invasive NIS (ISSG 2016), while the latter is listed as one of the 100 worst invasive NIS in Europe (DAISIE 2016).

For example, two nonindigenous macroalgae Schyzimenia dubyi and Ahnfeltiopsis sp. recently detected on the Argentinean coast around Mar del Plata modified the benthic habitat and altered the structure and composition of benthic biota (Palomo et al. 2016). The European green crab $(C$. maenas) significantly altered the community structure of local invertebrates in muddy habitats of Prince Edward Island, Canada by creating feeding pits in sediments (Lutz-Collins et al. 2016). Comparisons of meiofauna assemblages associated with bare sediments, the killer alga ( $C$. taxifolia), and the native seagrass Posidonia oceanica in the eastern Adriatic coast suggested that the invader altered the structure of meiofauna assemblages and caused a decline in meiofauna density (Cvitkovic et al. 2017). A laboratory experiment demonstrated that the nonindigenous Asian date mussel (A. senhousia) could disrupt benthic-pelagic coupling by reducing the ${ }^{13} \mathrm{C}$-uptake by the native clam Ruditapes decussatus and thus the availability of phytoplankton-derived C for deposit feeders (Como et al. 2016). Goren et al. (2016) reported that the food web structure of mixed native-nonindigenous fish communities in the Mediterranean Sea off the coast of Israel had undergone dramatic modifications as a result of increased dominance of nonindigenous fishes at the high trophic levels. A study quantifying losses of ecosystem services caused by the lionfish ( $P$. volitans/miles) in Bahamian reefs found losses of 26.67 and 21.67 discounted service unit years (DSUY) per $\mathrm{km}^{2}$ owing to reductions in recruitment and biomass of lionfish prey fishes (Johnston et al. 2015).

Negative impacts of NIS; however, may be mitigated by effective prevention and management efforts (Simberloff
2008). Fiori et al. (2016) developed a spatially explicit risk assessment to evaluate the potential effects of different strategies, including integral sanitation of the coastal zone, treatment of domestic sewage, and manual removal of oyster beds at specific locations, for managing the impacts of the Pacific oyster (Crassostrea gigas) in the Bahía Blanca estuary, Argentina. The potential effectiveness of individual approach is expected to vary depending on the location, though all approaches would offer risk reduction to some degree (Fiori et al. 2016).

\section{Conclusions}

Biological invasion is a major driver of global environmental change (Simberloff et al. 2013). While considerable research has been conducted to understand and predict invasions, the amount of effort devoted to these studies is not consistent across ecosystems, with the majority of the studies undertaken in terrestrial systems rather than aquatic ones (Jeschke et al. 2012; Lowry et al. 2012). This Topical Collection on Invasive Species addresses this knowledge and data gap by compiling some of the most recent research in marine invasion ecology. Articles in the collection considered a wide range of topics, including propagule pressure associated with transport vectors, species characteristics, attributes of recipient ecosystems, invasion genetics, biotic interactions, testing of invasion hypotheses, invasion dynamics and spread, and impacts of nonindigenous species. However, this collection is not by any means inclusive. For instance, the collection examined only two of the many important transport vectors of marine NIS (shipping and aquaculture). Other species traits in addition to physiological tolerance need to be investigated in future studies. Only three invasion hypotheses (ERH, NWH, and EICA) were empirically tested in studies of this collection. The inconsistent results obtained by these studies highlight the complexity and the context-dependent nature of biological invasion. Therefore, much research is still needed to advance the field.

Acknowledgements We thank all authors for their contribution to the topical collection and their patience and commitment during the review and editing process. We are grateful to the reviewers for their insightful comments on the manuscripts. We also thank the associate editors for their help with handling some of the manuscripts.

\section{Compliance with ethical standards}

Conflict of interest All authors declare they have no conflict of interest.

Ethical approval This article does not contain any studies with animals performed by any of the authors. 
Funding FTC was funded through the Natural Sciences and Engineering Research Council of Canada (NSERC) Visiting Fellowship at Fisheries and Oceans Canada. EB was supported by the Alexander von Humboldt Sofja Kovalevskaja Award.

Open Access This article is distributed under the terms of the Creative Commons Attribution 4.0 International License (http://creativecommons.org/licenses/by/4.0/), which permits unrestricted use, distribution, and reproduction in any medium, provided you give appropriate credit to the original author(s) and the source, provide a link to the Creative Commons license, and indicate if changes were made.

\section{References}

Alexander ME, Dick JTA, Weyl OLF et al (2014) Existing and emerging high impact invasive species are characterized by higher functional responses than natives. Biol Lett 10:20130946. doi:10.1098/rsbl.2013.0946

Alexander ME, Adams R, Dick JTA, Robinson TB (2015) Forecasting invasions: resource use by mussels informs invasion patterns along the South African coast. Mar Biol 162:2493-2500. doi:10.1007/s00227-015-2742-5

Alofs KM, Jackson DA (2014) Meta-analysis suggests biotic resitsnace in freshwater environments is driven by consumption rather than competition. Ecology 84:245-263. doi:10.1890/07-1861.1

Bates AE, McKelvie CM, Sorte CJB et al (2013) Geographical range, heat tolerance and invasion success in aquatic species. Proc $\mathrm{R}$ Soc B 280:20131958. doi:10.1098/rspb.2013.1958

Bierwagen SL, Price DK, Pack AA et al (2017) Bluespine Unicornfish (Naso unicornis) are both natural control agents and mobile vectors for invasive algae in a Hawaiian Marine Reserve. Mar Biol 164:25. doi:10.1007/s00227-016-3049-x

Blackburn TM, Jeschke JM (2009) Invasion success and threat status: two sides of a different coin. Ecography 32:83-88. doi:10.1111/j.1365-2486.2008.01841.x

Blackburn TM, Pyšek P, Bacher S et al (2011) A proposed unified framework for biological invasions. Trends Ecol Evol 26:333339. doi:10.1016/j.tree.2011.03.023

Blackburn TM, Lockwood JL, Cassey P (2015) The influence of numbers on invasion success. Mol Ecol 24:1942-1953. doi:10.1111/ mec. 13075

Blossey B, Nötzold R (1995) Evolution of increased competitive ability in invasive nonindigenous plants: a hypothesis. J Ecol 83:887-889. doi:10.2307/2261425

Bollen M, Pilditch CA, Battershill CN, Bischof K (2016) Salinity and temperature tolerance of the invasive alga Undaria pinnatifida and native New Zealand kelps: implications for competition. Mar Biol 163:194. doi:10.1007/s00227-016-2954-3

Bouchouicha-Smida D, Bates SS, Lundholm N et al (2015) Viability, growth and domoic acid toxicity of the diatom Nitzschia bizertensis following filtration by the mussel Mytilus sp. Mar Biol 162:2513-2519. doi:10.1007/s00227-015-2758-x

Briski E, Chan F (2015) Preface to "Invasive Species" Topical Collection. Mar Biol 162:2447-2448

Bugnot AB, Coleman RA, Figueira WF, Marzinelli EM (2016) Effects of the receiving assemblage and disturbance on the colonisation of an invasive species. Mar Biol 163:155. doi:10.1007/ s00227-016-2929-4

Callaway RM, Ridenour WM (2004) Novel weapons: invasive success and the evolution of increased competitive ability. Front Ecol Environ 2:436-443. doi: 10.1890/1540-9295(2004)002[0436:NWISAT ]2.0.CO;2
Carugati L, Corinaldesi C, Dell'Anno A, Danovaro R (2015) Metagenetic tools for the census of marine meiofaunal biodiversity: an overview. Mar Genomics 24:11-20. doi:10.1016/j. margen.2015.04.010

Casas-Monroy O, Parenteau M, Drake DAR et al (2016) Absolute estimates of the propagule pressure of viable dinoflagellates across Canadian coasts: the variable influence of ballast water exchange. Mar Biol 163:174. doi:10.1007/s00227-016-2946-3

Catford JA, Jansson R, Nilsson C (2009) Reducing redundancy in invasion ecology by integrating hypotheses into a single theoretical framework. Divers Distrib 15:22-40. doi:10.1111/j.1472-4642.2008.00521.x

Chan FT, MacIsaac HJ, Bailey SA (2016) Survival of ship biofouling assemblages during and after voyages to the Canadian Arctic. Mar Biol 163:250. doi:10.1007/s00227-016-3029-1

Choi FMP, Murray CC, Therriault TW, Pakhomov EA (2016) Intertidal invasion patterns in Canadian ports. Mar Biol 163:183. doi:10.1007/s00227-016-2957-0

Chu C, Mandrak NE, Minns CK (2005) Potential impacts of climate change on the distributions of several common and rare freshwater fishes in Canada. Divers Distrib 11:299-310. doi:10.1111/j.1366-9516.2005.00153.x

Clark GF, Johnston EL (2011) Temporal change in the diversity-invasibility relationship in the presence of a disturbance regime. Ecol Lett 14:52-57. doi:10.1111/j.1461-0248.2010.01550.x

Colautti RI, Ricciardi A, Grigorovich IA, MacIsaac HJ (2004) Is invasion success explained by the enemy release hypothesis? Ecol Lett 7:721-733. doi:10.1111/j.1461-0248.2004.00616.x

Como S, Pais A, Rumolo P et al (2016) Effects of an invasive mussel, Arcuatula senhousia, on local benthic consumers: a laboratory 13C-labeling study. Mar Biol 163:140. doi:10.1007/ s00227-016-2912-0

Cvitković I, Despalatović M, Žuljević A et al (2017) Structure of ebibiontic and sediment meiofauna in the area invaded by invasive alga Caulerpa taxifolia. Mar Biol 164:4. doi:10.1007/s00227-016-3034-4

DAISIE (2016) 100 of the worst. Delivering alien invasive species inventories for Europe (DAISIE). http://www.europe-aliens. org/speciesTheWorst.do. Accessed 26 Nov 2016

Davis MA, Grime JP, Thompson K (2000) Fluctuating resources in plant communities: a general theory of invasibility. J Ecol 88:528-534. doi:10.1046/j.1365-2745.2000.00473.x

Dick JTA, Alexander ME, Jeschke JM et al (2013) Advancing impact prediction and hypothesis testing in invasion ecology using a comparative functional response approach. Biol Invasions 16:735-753. doi:10.1007/s10530-013-0550-8

Drouin A, McKindsey CW, Johnson LE (2016) Dynamics of recruitment and establishment of the invasive seaweed Codium fragile within an eelgrass habitat. Mar Biol 163:61. doi:10.1007/s00227-016-2832-z

Elton CS (1958) The ecology of invasions by animals and plants. Methuen, London

Fiori SM, Pratolongo PD, Zalba SM et al (2016) Spatially explicit risk assessment for coastal invaders under different management scenarios. Mar Biol 163:245. doi:10.1007/ s00227-016-3017-5

Floerl O, Inglis GJ, Dey K, Smith A (2009) The importance of transport hubs in stepping-stone invasions. J Appl Ecol 46:37-45. doi:10.1111/j.1365-2664.2008.01540.x

Foster V, Giesler RJ, Wilson AMW et al (2016) Identifying the physical features of marina infrastructure associated with the presence of non-native species in the UK. Mar Biol 163:173. doi:10.1007/s00227-016-2941-8

Freestone AL, Ruiz GM, Torchin ME (2013) Stronger biotic resistance in tropics relative to temperate zone: effects of 
predation on marine invasion dynamics. Ecology 94:1370-1377. doi:10.1890/12-1382.1

Fridley AJD, Stachowicz JJ, Naeem S et al (2007) The invasion paradox: reconciling pattern and process in species invasions. Ecology 88:3-17. doi: 10.1890/0012-9658(2007)88[3:TIPRP A]2.0.CO;2

Gallardo B, Aldridge DC (2015) Is Great Britain heading for a Ponto-Caspian invasional meltdown? J Appl Ecol 52:41-49. doi:10.1111/1365-2664.12348

Gehrels H, Knysh KM, Boudreau M et al (2016) Hide and seek: habitat-mediated interactions between European green crabs and native mud crabs in Atlantic Canada. Mar Biol 163:152. doi:10.1007/s00227-016-2927-6

Goren M, Galil BS, Diamant A et al (2016) Invading up the food web? Invasive fish in the southeastern Mediterranean Sea. Mar Biol 163:180. doi:10.1007/s00227-016-2950-7

Guardiola M, Frotscher J, Uriz MJ (2016) High genetic diversity, phenotypic plasticity, and invasive potential of a recently introduced calcareous sponge, fast spreading across the Atlanto-Mediterranean basin. Mar Biol 163:123. doi:10.1007/ s00227-016-2862-6

Hammann M, Wang G, Boo SM et al (2016) Selection of heatshock resistance traits during the invasion of the seaweed Gracilaria vermiculophylla. Mar Biol 163:104. doi:10.1007/ s00227-016-2881-3

Herborg L-M, Rudnick DA, Siliang Y et al (2007) Predicting the range of Chinese mitten crabs in Europe. Conserv Biol 21:1316-1323. doi:10.1111/j.1523-1739.2007.00778.x

Hulme PE (2009) Trade, transport and trouble: managing invasive species pathways in an era of globalization. J Appl Ecol 46:10-18. doi:10.1111/j.1365-2664.2008.01600.x

ISSG (2016) 100 of the world's worst invasive alien species. Invasie Species Specialist Group (ISSG) Global Invasive Species Database. http://www.issg.org/worst100_species.html. Accessed 26 Nov 2016

James K, Shears NT (2016a) Population ecology of the invasive kelp Undaria pinnatifida towards the upper extreme of its temperature range. Mar Biol 163:225. doi:10.1007/s00227-016-2993-9

James K, Shears NT (2016b) Proliferation of the invasive kelp Undaria pinnatifida at aquaculture sites promotes spread to coastal reefs. Mar Biol 163:34. doi:10.1007/s00227-015-2811-9

Jeschke JM (2014) General hypotheses in invasion ecology. Divers Distrib 20:1229-1234. doi:10.1111/ddi.12258

Jeschke JM, Strayer DL (2006) Determinants of vertebrate invasion success in Europe and North America. Glob Change Biol 12:1608-1619. doi:10.1111/j.1365-2486.2006.01213.x

Jeschke JM, Gómez Aparicio L, Haider S et al (2012) Support for major hypotheses in invasion biology is uneven and declining. NeoBiota 14:1-20. doi:10.3897/neobiota.14.3435

Jeschke JM, Bacher S, Blackburn TM et al (2014) Defining the impact of non-native species. Conserv Biol 28:1188-1194. doi:10.1111/cobi.12299

Jiménez RS, Hepburn CD, Hyndes GA et al (2015) Do native subtidal grazers eat the invasive kelp Undaria pinnatifida? Mar Biol 162:2521-2526. doi:10.1007/s00227-015-2757-y

Johnson J, Bird CE, Johnston MA et al (2016) Regional genetic structure and genetic founder effects in the invasive lionfish: comparing the Gulf of Mexico, Caribbean and North Atlantic. Mar Biol 163:216. doi:10.1007/s00227-016-2981-0

Johnston MW, Akins JL (2016) The non-native royal damsel (Neopomacentrus cyanomos) in the southern Gulf of Mexico: an invasion risk? Mar Biol 163:12. doi:10.1007/ s00227-015-2777-7

Johnston MW, Bernard AM (2017) A bank divided: quantifying a spatial and temporal connectivity break between the Campeche
Bank and the north-eastern Gulf of Mexico. Mar Biol 164:12. doi:10.1007/s00227-016-3038-0

Johnston MW, Purkis SJ, Dodge RE (2015) Measuring Bahamian lionfish impacts to marine ecological services using habitat equivalency analysis. Mar Biol 162:2501-2512. doi:10.1007/ s00227-015-2745-2

Kauano R, Roper JJ, Rocha RM (2017) Small boats as vectors of marine invasion: neither speed nor desiccation limit transport. Mar Biol 164:27. doi:10.1007/s00227-016-3057-x

Kolar CS, Lodge DM (2001) Progress in invasion biology: predicting invaders. Trends Ecol Evol 16:199-204. doi:10.1016/ S0169-5347(01)02101-2

Kolar CS, Lodge DM (2002) Ecological predictions and risk assessment for alien fishes in North America. Science 298:1233-1236. doi:10.1126/science. 1075753

Larson ER, Gallagher RV, Beaumont LJ, Olden JD (2014) Generalized "avatar" niche shifts improve distribution models for invasive species. Divers Distrib 20:1296-1306. doi:10.1111/ ddi. 12233

Lau JA, Schultheis EH (2015) When two invasion hypotheses are better than one. New Phytol 205:958-960. doi:10.1111/nph.13260

Lee CE (2002) Evolutionary genetics of invasive species. Trends Ecol Evol 17:386-391. doi:10.1016/S0169-5347(02)02554-5

Lejeusne C, Saunier A, Petit N et al (2014) High genetic diversity and absence of founder effects in a worldwide aquatic invader. Sci Rep 4:5808. doi:10.1038/srep05808

Lenz M, da Gama BAP, Gerner NV et al (2011) Non-native marine invertebrates are more tolerant towards environmental stress than taxonomically related native species: results from a globally replicated study. Environ Res 111:943-952. doi:10.1016/j. envres.2011.05.001

Levine JM, Adler PB, Yelenik SG (2004) A meta-analysis of biotic resistance to exotic plant invasions. Ecol Lett 7:975-989. doi:10.1111/j.1461-0248.2004.00657.x

Lockwood JL, Cassey P, Blackburn TM (2005) The role of propagule pressure in explaining species invasions. Trends Ecol Evol 20:223-228. doi:10.1016/j.tree.2005.02.004

Lodge DM (1993) Biological invasions: lessons for ecology. Trends Ecol Evol 8:133-136. doi:10.1016/0169-5347(93)90025-K

Lonsdale WM (1999) Global patterns of plant invasions and the concept of invasibility. Ecology 80:1522-1536. doi: 10.1890/0012-9658(1999)080[1522:GPOPIA]2.0.CO;2

Lord JP, Calini JM, Whitlatch RB (2015) Influence of seawater temperature and shipping on the spread and establishment of marine fouling species. Mar Biol 162:2481-2492. doi:10.1007/ s00227-015-2737-2

Lowry E, Rollinson EJ, Laybourn AJ et al (2012) Biological invasions: a field synopsis, systematic review, and database of the literature. Ecol Evol 3:182-196. doi:10.1002/ece3.431

Lutz-Collins V, Cox R, Quijón PA (2016) Habitat disruption by a coastal invader: local community change in Atlantic Canada sedimentary habitats. Mar Biol 163:177. doi:10.1007/ s00227-016-2947-2

Marchini A, Cardeccia A (2017) Alien amphipods in a sea of troubles: cryptogenic species, unresolved taxonomy and overlooked introductions. Mar Biol 164:69. doi:10.1007/ s00227-017-3093-1

Marini L, Bertolli A, Bona E et al (2013) Beta-diversity patterns elucidate mechanisms of alien plant invasion in mountains. Glob Ecol Biogeogr 22:450-460. doi:10.1111/geb.12006

Melbourne BA, Cornell HV, Davies KF et al (2007) Invasion in a heterogeneous world: resistance, coexistence or hostile takeover? Ecol Lett 10:77-94. doi:10.1111/j.1461-0248.2006.00987.x

Merella P, Pais A, Follesa MC et al (2016) Parasites and Lessepsian migration of Fistularia commersonii (Osteichthyes, 
Fistulariidae): shadows and light on the enemy release hypothesis. Mar Biol 163:97. doi:10.1007/s00227-016-2865-3

Miller KB (2016) Forecasting at the edge of the niche: Didemnum vexillum in Southeast Alaska. Mar Biol 163:30. doi:10.1007/ s00227-015-2799-1

Molnar JL, Gamboa RL, Revenga C, Spalding MD (2008) Assessing the global threat of invasive species to marine biodiversity. Front Ecol Environ 6:485-492. doi:10.1890/070064

Morelissen B, Dudley BD, Phillips NE (2016) Recruitment of the invasive kelp Undaria pinnatifida does not always benefit from disturbance to native algal communities in low-intertidal habitats. Mar Biol 163:241. doi:10.1007/s00227-016-3014-8

Muirhead JR, MacIsaac HJ (2005) Development of inland lakes as hubs in an invasion network. J Appl Ecol 42:80-90. doi:10.1111/j.1365-2664.2004.00988.x

Occhipinti-Ambrogi A, Savini D (2003) Biological invasions as a component of global change in stressed marine ecosystems. Mar Pollut Bull 46:542-551. doi:10.1016/S0025-326X(02)00363-6

Palomo MG, Bagur M, Quiroga M et al (2016) Ecological impacts of two non-indigenous macroalgae on an urban rocky intertidal shore. Mar Biol 163:178. doi:10.1007/s00227-016-2951-6

Pedersen MF, Johnsen KL, Halle LL et al (2016) Enemy release an unlikely explanation for the invasive potential of the brown alga Sargassum muticum: experimental results, literature review and meta-analysis. Mar Biol 163:197. doi:10.1007/ s00227-016-2968-x

Pennoyer KE, Himes AR, Frederich M (2016) Effects of sex and color phase on ion regulation in the invasive European green crab, Carcinus maenas. Mar Biol 163:137. doi:10.1007/ s00227-016-2910-2

Peterson AT (2003) Predicting the geography of species' invasions via ecological niche modeling. Q Rev Biol 78:419-433. doi:10.1086/378926

Piazzi L, Balata D, Bulleri F et al (2016) The invasion of Caulerpa cylindracea in the Mediterranean: the known, the unknown and the knowable. Mar Biol 163:161. doi:10.1007/ s00227-016-2937-4

Pineda MC, Turon X, Pérez-Portela R, López-Legentil S (2016) Stable populations in unstable habitats: temporal genetic structure of the introduced ascidian Styela plicata in North Carolina. Mar Biol 163:59. doi:10.1007/s00227-016-2829-7

Podbielski I, Bock C, Lenz M, Melzner F (2016) Using the critical salinity $\left(\mathrm{S}_{\text {crit }}\right)$ concept to predict invasion potential of the anemone Diadumene lineata in the Baltic Sea. Mar Biol 163:227. doi:10.1007/s00227-016-2989-5

Prior KM, Powell THQ, Joseph AL, Hellmann JJ (2015) Insights from community ecology into the role of enemy release in causing invasion success: the importance of native enemy effects. Biol Invasions 17:1283-1297. doi:10.1007/s10530-014-0800-4

Pyšek P, Richardson DM (2010) Invasive species, environmental change and management, and health. Annu Rev Environ Resour 35:25-55. doi:10.1146/annurev-environ-033009-095548

Quinn BK, Boudreau MR (2016) Kleptoparasitism and scavenging by the invasive green crab (Carcinus maenas) have different impacts on native species. Mar Biol 163:186. doi:10.1007/ s00227-016-2964-1

Ricciardi A, MacIsaac HJ (2011) Impacts of Biological invasions on freshwater ecosystems. In: Richardson DM (ed) Fifty Years of Invasion Ecology: The Legacy of Charles Elton, 1st edn. WileyBlackwell, West Sussex, pp 211-224

Roman J, Darling JA (2007) Paradox lost: genetic diversity and the success of aquatic invasions. Trends Ecol Evol 22:454-464. doi:10.1016/j.tree.2007.07.002

Ruiz GM, Fofonoff PW, Ashton GV et al (2013) Geographic variation in marine invasions among large estuaries: effects of ships and time. Ecol Appl 23:311-320. doi:10.2307/23440996
Sagerman J, Enge S, Pavia H, Wikström SA (2015) Low feeding preference of native herbivores for the successful non-native seaweed Heterosiphonia japonica. Mar Biol 162:2471-2479. doi:10.1007/s00227-015-2730-9

Sakai AK, Allendorf FW, Holt JS et al (2001) The population biology of invasive species. Annu Rev Ecol Syst 32:305-332. doi:10.1146/annurev.ecolsys.32.081501.114037

Sax DF, Stachowicz JJ, Brown JH et al (2007) Ecological and evolutionary insights from species invasions. Trends Ecol Evol 22:465-471. doi:10.1016/j.tree.2007.06.009

Schmidt C, Morard R, Prazeres M et al (2016) Retention of high thermal tolerance in the invasive foraminifera Amphistegina lobifera from the Eastern Mediterranean and the Gulf of Aqaba. Mar Biol 163:228. doi:10.1007/s00227-016-2998-4

Schwartz N, Rohde S, Hiromori S, Schupp PJ (2016) Understanding the invasion success of Sargassum muticum: herbivore preferences for native and invasive Sargassum spp. Mar Biol 163:181. doi:10.1007/s00227-016-2953-4

Sherman CDH, Lotterhos KE, Richardson MF et al (2016) What are we missing about marine invasions? Filling in the gaps with evolutionary genomics. Mar Biol 163:198. doi:10.1007/ s00227-016-2961-4

Silva AG, Fortunato HFM, Lôbo-Hajdu Fleury BG (2017) Response of native marine sponges to invasive Tubastraea corals: a cast study. Mar Biol 164:78. doi:10.1007/s00227-017-3112-2

Simberloff D (2008) We can elimiante invasions or live with them. Successful management projects. Biol Invasions 11:149-157. doi:10.1007/s10530-008-9317-z

Simberloff D (2009) The role of propagule pressure in biological invasions. Annu Rev Ecol Evol Syst 40:81-102. doi:10.1146/ annurev.ecolsys.110308.120304

Simberloff D, Von Holle B (1999) Positive interactions of nonindigenous species: invasional meltdown? Biol Invasions 1:21-32. doi:10.1023/A:1010086329619

Simberloff D, Martin J-L, Genovesi P et al (2013) Impacts of biological invasions: what's what and the way forward. Trends Ecol Evol 28:58-66. doi:10.1016/j.tree.2012.07.013

Simkanin C, Fofonoff PW, Larson K et al (2016) Spatial and temporal dynamics of ascidian invasions in the continental United States and Alaska. Mar Biol 163:163. doi:10.1007/ s00227-016-2924-9

Simmons M, Tucker A, Chadderton WL et al (2016) Active and passive environmental DNA surveillance of aquatic invasive species. Can Fish Aquat Sci 73:76-83. doi:10.1139/ cjfas-2015-0262

South PM, Thomsen MS (2016) The ecological role of invading Undaria pinnatifida: an experimental test of the driver-passenger models. Mar Biol 163:175. doi:10.1007/s00227-016-2948-1

Sun Y, Wong E, Keppel E et al (2017) A global invader or a complex of regionally distributed species? Clarifying the status of an invasive calcareous tubeworm Hydroides dianthus (Verrill, 1873) (Polychaeta: Serpulidae) using DNA barcoding. Mar Biol 164:28. doi:10.1007/s00227-016-3058-9

van der Gaag M, van der Velde G, Wijnhoven S, Leuven RSEW (2016) Salinity as a barrier for ship hull-related dispersal and invasiveness of dreissenid and mytilid bivalves. Mar Biol 163:147. doi:10.1007/s00227-016-2926-7

Von Holle B, Simberloff D (2005) Ecological resistance to biological invasion overwhelmed by propagule pressure. Ecology 86:3212-3218. doi:10.1890/05-0427

Williams SL, Davidson IC, Pasari JR et al (2013) Managing multiple vectors for marine invasions in an increasingly connected world. Bioscience 63:952-966. doi:10.1525/bio.2013.63.12.8

Williamson MH (2006) Explaining and predicting the success of invading species at different stages of invasion. Biol Invasions 8:1561-1568. doi:10.1007/s10530-005-5849-7 
Wilson JRU, Dormontt EE, Prentis PJ et al (2009) Something in the way you move: dispersal pathways affect invasion success. Trends Ecol Evol 24:136-144. doi:10.1016/j.tree.2008.10.007

Xavier JC, Peck LS, Fretwell P, Turner J (2016) Climate change and polar range expansions: could cuttlefish cross the Arctic? Mar Biol 163:78. doi:10.1007/s00227-016-2850-x

Xiong W, Li H, Zhan A (2016) Early detection of invasive species in marine ecosystems using high-throughput sequencing: technical challenges and possible solutions. Mar Biol 163:139. doi:10.1007/ s00227-016-2911-1
Zhan A, Hulák M, Sylvester F et al (2013) High sensitivity of 454 pyrosequencing for detection of rare species in aquatic communities. Methods Ecol Evol 4:558-565. doi:10.1111/2041-210X.12037

Zhan A, Briski E, Bock DG et al (2015) Ascidians as models for studying invasion success. Mar Biol 162:2449-2470. doi:10.1007/ s00227-015-2734-5 